Article

\title{
The Scarecrow as an Indicator of Changes in the Cultural Heritage of Rural Poland
}

\author{
Karol Król ${ }^{1, *(1)}$, Robert Kao ${ }^{2}$ and Józef Hernik ${ }^{1}$ \\ 1 Department of Land Management and Landscape Architecture, Faculty of Environmental Engineering and \\ Land Surveying, University of Agriculture in Kraków, Balicka 253c, 30-149 Kraków, Poland; \\ rmhernik@cyf-kr.edu.pl \\ 2 Department of Accounting, Economics, and Finance, College of Management, School of Business, Park \\ University, 8700 River Park Drive, Parkville, MO 64152, USA; rkao@park.edu \\ * Correspondence: k.krol@onet.com.pl; Tel.: +48-12-662-40-16
}

Received: 30 September 2019; Accepted: 25 November 2019; Published: 2 December 2019

check for updates

\begin{abstract}
Scarecrows were commonly featuredin rural landscapes until recently. There are numerous rituals associated with creating a scarecrow and erecting it in the field, with many legends being linked to this character.The scarecrow itself has counterparts in many countries worldwide. However, with civilisation progressingand characterised withan emphasis on economic efficiency and agricultural engineering in the present day, scarecrows are disappearing from the rural landscape. Advanced electronic devices replace them, while scarecrows end up in museums and open-air museums calledskansens, as well as beingon display at local village festivals. The goal of this paper is to investigate the past and present functions of the scarecrow in rural areas in Poland as an indicator of changes occurring inthe cultural heritage in these areas. The survey and field studies were carried out in selected localities in Małopolskie Voivodeship that exhibited distinct qualities related to rural cultural heritage. The study involved photographic documentation and a diagnostic survey using the structured direct interview technique. The interview focused on local community leaders. Resultingly, scarecrows were demonstrated to be an essential indicator of changes in Poland's rural cultural heritage.
\end{abstract}

Keywords: scarecrow; folk customs; cultural heritage; rural areas; socio-economic development

\section{Introduction}

Urbanisation is one of the essential characteristics of European civilisation. The polarisation of territory between urban and rural lands as well as its accessibility are still important aspects in landscape dynamics [1]. Landscapes are closely related to people's prosperity, but they undergo rapid and fundamental changes. Understanding the social transformation underlying these landscape changes as well as the environmental and social results of landscape transformations on various scales are the main areas of research regarding landscapes [2-4]. A local change in the landscape can only be understood where it is situated in the general geographical context and with all the associated dynamics maintained. Change patterns are different for villages in the vicinity of large cities, metropolises, and remotely located villages. Transformations occurring in rural areas are due to a variety of factors that bring about changes in the rural landscape. The varied effects of changes in the rural landscape are often adverse in nature and are manifested among other things in the stagnation of improvements on land with a tendency towards buildings disappearing, or the degradation of old, historical parts of a village, such as the former palace complexes with farm buildings or post-industrial structures. These changes cause the fading of the traditions of the location, distinctiveness, and regional specificity of the countryside [1]. 
The distinguishing feature of rural landscapes is a tangible or intangible carrier of either the characteristic features of the rural landscape or the ones based on its dissimilarity and/or contrast, also in terms of uniqueness. Cultural ecosystem services embody the intangible benefits of agricultural landscapes, such as aesthetical values, leisure, inspiration, and cultural heritage [5]. The distinguishing features of the rural landscape in relation to a particular locality can be considered, depending on the type (tangible or intangible), the origin (natural or anthropogenic), or the time of formation (historical or contemporary). Identifying the distinguishing features of the landscape of a particular village allows its landscape to be shaped as a continuation, while respecting the conditions already in place [6].

The scarecrow has always had its place in the rural landscape, not only in Poland, but throughout Europe and in many other countries worldwide. The scarecrow is a product of a culture inseparably linked with agriculture. Scarecrowsare found in a variety of forms worldwide, from New Guinea through the Arab world to the prairies [7]. Instantly recognisable, it is thought to be a premodern form of deception devised by the earliest pastoral peoples [8]. A scarecrow's ragged figure has appeared in various historical records for centuries. By tradition, a scarecrow isthe crudest type of mannequin, styled somewhere between the grotesque and the carnivalesque. It has a head, arms, and a torso, although legs are often absent. Instead, a single vertical stake, which serves as his spine, is driven deep into the loose, tilled earth [9] (p. 178). The scarecrow character has attracted the attention of well-known writers, including William Shakespeare and Walter de la Mare, as well as filmmakers [10]. The existence of this striking farmland contraption is variously reported as having all but vanished and yet of making unexpected reappearances; as materially functional and complexly meaningful; as a figure summoned up by cultural memory and personal recollection; and as a focus for mixed feelings of loss, nostalgia, estrangement, and community [9]. However, despite all of its "fame", the origin of the scarecrow remains shrouded in mystery.

Villages and small towns are usually surrounded by cultivated fields and gardens, with meadows, peatbogs, broad-leaved and coniferous forests, as well as other types of vegetation (grassland, heathland, etc.) stretching away behind them. This kind of characteristic sight can be admired while travelling across suburban and rural areas. Until recently, scarecrows were a commonly found feature of such a landscape [9].

The presence of the scarecrow in a cultivated field no longer matters. Technological development and the pursuit of production efficiency have resulted in the scarecrow becoming a relic of the past. Hitherto conspicuous, it is currently slowly disappearing from the rural landscape [9]. In the not too distant past, every year a farmer did the sowing after he had carefully prepared the soil. Most of the work was done manually using simple tools. This does not mean that those times "were better". This means that humans used to be closer to nature; they lived in harmony with nature and according to the rhythm of nature. A farmer would throw away his old clothes and created a "friendly boy" who was supposed to guard the crops. The scarecrow was not just a couple of planks nailed together and bedecked with old rags, but a real-life figure who inspired respect, was supposed to be greeted, and with whom one could have a word. Joyce Warren, a professional Scarecrow Artist, believes that if the scarecrow is going to do its job, it has to have a mystical feel about it [11]. Meanwhile, contemporary farmers lead hectic lives and have no time to commune with nature and listen to its voice. They sit in a modern and air-conditioned machine protecting them from the elements, possibly listening to music. They are high above the ground, and cultivated fields and the miracle of yielding are reduced alike to a methodological factory. Crops are protected by machinery and equipment, while electric scarers and chemicals enable the intensification of production on an industrial scale. Scarecrows have reappeared in a new version, as either mechanical or electric devices.

Nowadays, scarecrows are only perceived from the angle of the role they are supposed to serve in the protection of cultivated fields. The scarecrow understood in this way takes on different forms, such as raptor-shaped kites, balloons, flashing or revolving lights, and barriers like netting or grid wires. Their effectiveness is increased through the use of various dummies and mock-ups, reflective pillars, sound emitters, alarms, pyrotechnical materials, or recorded animal sounds [12]. However, these are 
"scarers" (deterrents), for example, a cannon repeller can be deployed rather than the traditionally understood scarecrows. These kinds of devices can produce the sound of firearms or a siren, or even imitate animal noises. Selected devices rely on animals' natural fear of humans and sudden, rapid movements. Modern bird scarers and deterrents combine sound and visual signals. Scarecrows are an indicator of cultural changes occurring in rural areas. The goal of this paper is to investigate the past and present functions of the scarecrow in rural areas in Poland, as an indicator of changes in cultural heritage of these areas.

The objective of the work required a review of the literature on sustainable development and cultural heritage in rural areas. International literature on scarecrows was analysed in depth. Their rural, rustic nature was emphasised. Model scarecrows from different countries in the world and legends and beliefs related to the scarecrow were presented. The cultural role of the scarecrow in rural areas was discussed. Next, cultural changes regarding the perception of scarecrows were depicted, including the replacement of the mannequin stuffed with straw by an electronic device. The following part contains results of fieldwork involving in-depth interview. The results were discussed and summarised.

\section{Literature Review: Cultural Heritage and Sustainability}

Sustainable development is a 'development that meets the needs of the present without compromising the ability of future generations to meet their own needs' [13] (p. 43). This definition essentially concerns the global and intergenerational equality and fairness regarding the distribution of prosperity, services, and resources among generations [14]. Sustainable development is often considered to consist of ecological, economic, and social dimensions [15]. The origins of sustainable development lie in the care for the natural environment. That is why this aspect is the most popular. Sustainable economic development is seldom discussed on its own. It is mentionedmost frequently in the context of the green economy, green or blue-green infrastructure, or bioeconomy aimed at combining ecological and social goals of sustainable development through economic means [14]. Sustainable development encompasses responsibility for the environment, economy, social justice, and sustainable cultural development. Cultural sustainability includes the basic human need to participate in cultural activities, which takes into account the achievements of the past and allows future generations to understand past experiences [16].

Cultural assetsare any moveable or immovable, past or modern object important for its cultural heritage and development because of its historical, scientific, or artistic value. Cultural heritage is a complex and multifaceted notion. Just like culture itself, it cannot be measured and resists specific definitions. Generally, heritage consists of assets that include the natural and cultural environment, landscape, historic sites, objects, structures, and monuments. Hence, cultural heritage comprises material and spiritual cultural assets together with the cultural landscape [17]. Cultural heritage consists of cultural assets that have been considered valuable, which allowed them to survive into the present day.

In the UNESCO Convention Concerning the Protection of the World Cultural and Natural Heritage (1972), the expression, 'cultural heritage' covers the monuments, groups of buildings, and sites that are of 'outstanding universal value for history, art, or science' [18]. Furthermore, non-material forms of cultural heritage are attracting growing attention [19]. Non-material heritage includes cultural elements like oral and written traditions, poetry, art, music, dance, clothing, weaving designs, food, and recipes. Such assets are more ephemeral than buildings or cityscapes and still remain essential parts of the culture [16]. Non-material cultural heritage has been ignored in preservation attempts for a long time [18].

Cultural heritage is a strategic resource, which may improve the attractiveness and competitive advantage of a region. It is considered an important local resource capable of generating social and environmental benefits as well as contributing towards community-led development [20]. Cultural heritage in many rural locations operates on several levels, from professional museums and council-run 
services through to voluntary groups such as historical societies [21]. Cultural heritage, such as buildings, places, or sites; or more generally defined to be a cultural environment or aura of historical cities is an essential driver of tourist demand. In turn, the latter can stimulate social and economic development [22].

Cultural heritage and sustainability are two interconnected concepts that have found their way into international cultural conservation policies over the past decade. Cultural resources are material and non-material remains of societies' past activities on the biophysical environment, which are transformed into various forms of the cultural heritage [23]. The sustainability of cultural heritage has been identified as a complex value with multiple dimensions: physical, social, economic, cultural, and environmental. Cultural heritage has become the core of development strategies, in which buildings and landscapes, as well ascustoms and food, provide economic benefits to local communities. In principle, cultural heritage focuseson aspects well-known to residents, but considered exceptional by outsiders. This phenomenon stems from the past historical narratives that can be moulded around an object or activity, thus becoming more interesting to the audience.

Contrastingly, in general, sustainable development is associated with the ecological perspective and the environment via the notion that living conditions can be improved through development free of natural environmental resources degrading. Sustainable development, both as an idea and practical approach, is broadly involved in the provision of food, water and air cleanliness, reasonable use of natural resources, promotion of culture, and education. Cultural heritage and sustainable development respects both the achievements of the past and an outlook of the future. Human activity is perceived in this context to be the sum of the past legacy and future potential [16].

\subsection{The Scarecrow as a Part of Cultural Heritage of Rural Areas}

The key issue in deliberations on sustainable development in the 1970s was the problem of dwindling natural resources in the face of progressing economic and demographic growth together with relevant environmental threats. The next decade brought a general definition of sustainable development. It states that sustainable development is the way of providing for the needs of the current generation without hindering the ability of future generations to meet their needs. It was not until the Rio de Janeiro summit that the environmental and socio-economic factors were considered equal. Sustainable development became a strategy for identifying and resolving economic, social, and environmental problems. Its essence is to ensure improved life quality for current and future generations through establishing the right proportions of three types of capital, economic, human, and environmental [24]. This applies to rural areas as well.

The literature offers multiple definitions of rural areas. The best-accepted one may be the traditional definition that the rural area is a physical space with a relatively low population density, scattered settlement structure, and extensive use of land [25]. Rural development is a persistent challenge everywhere, whether in advanced industrial and post-industrial economies or less developed settings [21]. The concept of sustainable rural development involves simultaneous effort towards improved life quality and continuous business operations in the areas. At the same time, it calls for the protection of specific rural resources such as the natural environment, landscape, or cultural heritage [24]. It may be a challenge as people with their holdings coexist in rural areas with nature to make up a specific whole. Interactions are unavoidable.

Ever since people devoted themselves to land cultivation, birds have been the greatest threat to sowing and harvesting. In the years of crop failure, the damage inflicted by pestlike birds on crops could even lead a family to starvation in the winter. In order to prevent this, family members used to guard their fields, and farmers eventually began to invent and create scarecrows to deter birds.

A variety of methods for scaring birds away were used in Egypt more than 3000 years ago. Dummies resembling scarecrows used to be set up on the Nile riverbanks to protect fields of wheat against flocks of quails that flew over them while migrating to the south during autumn. Moreover, farmers constructed wooden frames, covered them with fine-mesh fishing nets, and placed these 
protective devices on sown fields. Next, they tied long strips of white fabric to their own bodies and hid to wait for the birds to come. As soon as the birds appeared, the farmerswould run into the field making a lot of noise and waving their flags. The preserved records reveal that the birds were so stunned that most of them fell into the previously prepared nets and got trapped. The birds captured in this way were subsequently dressed and eaten by the farmer's family [26].

The daily life of villagers was inseparably accompanied with scarecrows. They were not living creatures, but dummies made of straw and worn-out clothes. The task of scarecrows standing in fields, orchards, and farmyards was to deter wild animals and birds. Folk chronicles reveal "there were indeed scarecrows galore standing in fields."Furthermore, each one was described as being more elegant than the one before. It was sometimes hard to tell whether it was a peasant stretching his legs in the field after work, or a strawman watching over the crops [27] (p. 59).

The scarecrow is a guard of the fruits of a farmer's work. It is feared by birds, deer, and wild boars. It usually stands in a field of potatoes, oats, corn, or rye. Scarecrows can be located at the corners of the field, facing the other way. Sometimes they are also placed in rows along the field or from the side of the road, facing southwards, with their arms pointing to the area they guarded. The scarecrow takes on a human form, but in a caricatured fashion, slightly misshapen; sometimes scary, in an offensive, threatening, and inaccessible posture. For example, the Podhale strawmen and "lame fellows" appear in this manner. However, at the same time, the scarecrow is sometimes associated with a "good spirit", something positive, pleasant, and useful at the same time [28]. This "quasi-human" standing alone in the field is a symbol of the folk, agricultural culture and the peasants' hope for an abundant yield. It sometimes happens that scarecrows take on the form of non-existent beings, creatures on long legs, with the head of giant owls or bats. There are also "tiny scarecrows" set up in potato fields and waving empty shirt sleeves, or "abstract scarecrows", which have spatial compositions resembling no living creatures. Scarecrows of a movement and acoustic design, bedecked with bottles, empty cans, or old $\mathrm{CDs}$ can also be encountered. The design of a traditional scarecrow, however, is almost always based on a wooden or metal cross, with a height ranging from approximately $50 \mathrm{~cm}$ to even $3 \mathrm{~m}$, excluding the part underground approximately $60 \mathrm{~cm}$ deep. Old clothes, bags, hats, helmets, and saucepans as well as various noise-producing objects, such as bottles, lids, and cans are hung on the rack. The heads are made of old rags stuffed with straw [29]. They perch high above gardens and fields with borrowed coats, button eyes, and pie-pan hands that glint in the sun. The scarecrow doesnot care what it is made of or how long it might last, becauseit has been a witness to life. The earth has rained, snowed, blossomed, wilted, yellowed, greened, and vined itself all around the scarecrow [30].

In Brazil, scarecrows bear the name of "Espantalho", and are usually set up in rice fields, although they are also placed in gardens. In general, in Spanish-speaking countries, the scarecrow is called "Espantapájaros". In France, it is referred to as "Epouvantail", in Italy as "Spaventa-pássaro", and in the Netherlands as"Volgerverschrikker". In Germany and Austria, the scarecrow is known as, "Vogelscheuche", while in English-speaking countries, it is most commonly referred to as the "scarecrow". The Zumi Indians from North America call it, "Guardião das SementesBrotadas" [31], which literally means "the protector of germinating seeds".

The scarecrow once used to be something more than just a field guard. It was a peculiar and unique "idol", Svetovid of the baulk, who guarded the crops while serving an additional, magical, and ritualistic role. This character is a remnant of old pagan wizardry that has survived centuries. Scarecrows and its associated rituals and customs are an unusual element of folk demonology, the colourful area of human culture, as well as ancestors' beliefs and their customs [28].

The origins of the scarecrow can be traced back to the distant past when, along with the spread of agriculture, various crop protection measures began to be taken. The first records on scarecrows in Europe date back to 1592. The prototype of the scarecrow were objects and material items used by humans daily in magic practices, rituals, and ceremonies associated with the cultivation cycle and process. Therefore, a certain primary form of the scarecrow was not a man of straw, but objects aimed at deterring everything that could pose a threat to crops, including malevolent supernatural forces [7]. 
"His coat was black and his head hung low, and as the wind shook him the crows took into the air" (Mike Waterson, The Scarecrow lyrics) [30]. Scarecrows used to occupy a permanent place in Poland's rural landscape and were commonly found. They were placed in gardens, in cultivated fields, near roads, in cherry orchards, and in cabbage or maize fields. The scarecrow was one of the first effigies of a human figure of natural size that had a universal and basic representation of the human self. Rich in symbolic meanings, itevoked an emotional response. The scarecrow symbolised hunger and hope for a better harvest. It was a physical manifestation of demands for ownership and faith, as well as the tangible desires and needs of the family. It is believed that in the Middle Ages, scarecrows played a mystical role in pagan rituals as a surrogate for human sacrifice. In pastoral myths, the scarecrow acts as a gentle and benevolent character that poses no threat to birds or forest animals [9].

Beboks, spells, lame fellows, or bogeymen; differently referred to in various regions of Poland, scarecrows are known worldwide. They usually take up features specific to a particular location. Those used in Cambodia are often equipped with spears and wooden rifles. In Asian countries, they wear characteristic cone-shaped hats similar to the headgear worn by its local communities. Across countries and within its regional cultures, the scarecrow is known by different names. In the United Kingdom, the scarecrow is referred to as mommet (Somerset), murmet (Devon), mammet (Yorkshire, Lancashire), hodmedod—with a hat and a stick (Berkshire, Isle of Wight)—tattie bogies (Potato Fields), tattie bouie, craw bogie, or mawhini (Suffolk, Norfolk, East Anglia) [9]. In Poland, in the Żywiec Beskids, scarecrows were called "beboks", while in the Subcarpathia, they were referred to as "tramps" or "bodos", while in certain villages, the term "mamunas" was used to describe the scarecrow if it was dressed in women's clothes. In the NowySacz city area, found in the BeskidSacecki range, as well as in the Podhale region, the scarecrow was called a "lame fellow"; in the vicinity of the city of Kraków, scarecrows were referred to as "puheroks". In Ukraine, in the vicinity of the cities Lviv and Sambor, scarecrows are known as "puhalo", while the Lemkos refer to the scarecrow as a "did" (a tramp or beggar). In certain regions where Arabic culture is dominant, such as in the Middle East, scarecrows are "kanturas" [28].

In folk oral traditions, the quasi-person called a "bebok" is a peculiar character. The referent of the lexeme "bebok" is "all kinds of bogeymen, fear". The "bebok" is a supernatural character that scares children and resembles an owl, a creature, a small shaggy little man with an old, wrinkled face, a giant with a big head, hooves, and with a large bag to which he kidnaps children, or a tiny little devil. Sometimes a bebok's selected attributes like glowing eyes are additionally emphasised. The scarecrow used to be referred to as a "bebok" as well [31].

In Old Polish beliefs, mamunas are forest demons taking up the form of young girls. According to oral traditions, mamunas primarily beguiled young men and led them to the crossroads or swamps that they used to kill them.

Scarecrows also have local names. For example, in Poland, in the vicinity of the locality of Sołonka (Podkarpackie Voivodeship, Rzeszowski District, the commune of Lubenia), scarecrows in the 1980s, or at least those made by WładysławSzypuła, were called "clatterers". The name resulted from the ingenious design that made the scarecrow emit, thanks to a special lever, terrifying clattering sounds that deterred birds.

A traditional Polish scarecrow was rather poor, but looked slightly elegant. Its clothes, usually made up of tattered rags, were always crowned with a more or less dignified hat. This figure was commonly adorned and often rattled with cans and rustled with plastic film. Afterall, the scarecrow's essential task was to scare animals away. The scarecrow started its work in the spring during the growing season. Throughout the summer, it protected fields and orchards, finishingits work in the autumn. The scarecrow's task was to deter game, in particular, wild boars and deer, as well as birds, especially starlings feeding on fruit growing on trees, or crows picking up small chickens from yards [32].

Traditional scarecrows are not puppets. They are supposed to frighten with their posture, appearance, and the sounds they make. In Poland, the colloquiallycalled Podhale tramps and lame 
fellows resemble a human, however, in a caricatural form as scary and evil, and assume an offensive, threatening, and unapproachable pose. They can also resemble an imaginary being, a creature on long legs, with the head of an owl or a horse. They can also be small "scarers" in a potato field, or "abstract strawmen" flapping empty shirt sleeves. Scarecrows also take the form of spatial compositions free of any associations, or intricately crafted metal windmills stuck in the soil to scare moles away from vegetable gardens. The smallest of them were up to half a metre tall, while the largest ones reached a height of up to $3-4$ metres.

Scarecrows have taken a variety of forms. Their design was usually based on crossed wooden poles, planks, or branches, tied with a rope to ensure flexibility. Under the influence of wind, the scarecrow danced and whirled with his sleeves flapping cheerfully. Straw gave his body roundness. A turnip or pumpkin acted as a makeshift a head. Rough cuts in the flesh open up holes where, by human rights, a pair of eyes and mouth should be. Such a support frame was adorned to resemble a human figure, usually a man, by putting worn-out, old clothes on it. Frequently, any object within reach was used, including worn-out articles, dishes, or packaging, often without paying attention to due care of workmanship (Figure 1). Dead birds were often hung up in the vicinity of scarecrows with the intention of increasing the effect of animal deterrence (Figure 2). Additionally, fences, including those made of barbed wire, were most commonly used to protect crops against wild boars (Figure 3). The field scarecrow was also used in home vegetable gardens (Figure 4). The story goes that in the past, his outfit comprised articles removed from a dead man's wardrobe; one source seemingly suggests the scarecrow has a long-standing association with things sinister and of supernaturalpresences. Gaunt and solitary, it is a watcher and a keeper, affixed in a permanent state of wakefulness. Flapping, but entirely unflinching. Certainly not aclockwatcher, it goes unpaid, but is uncomplaining. Nameless, its vigil sees out all weathers. A knot of mysteries, an old soul, honest to himself. Foursquare. Or so it seemed [9] (p. 178). The concept of balance is central to the nature of the scarecrow, as indeed, its own morphology points towards equilibrium. In various cultures, scarecrows are used to protect crops by frightening birds and with extra emphasis, without harming them. Implicit in this is a respect for the balance in nature, for the hostile as well as the benign [33].

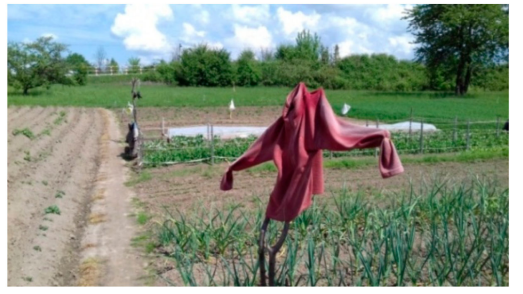

(a)

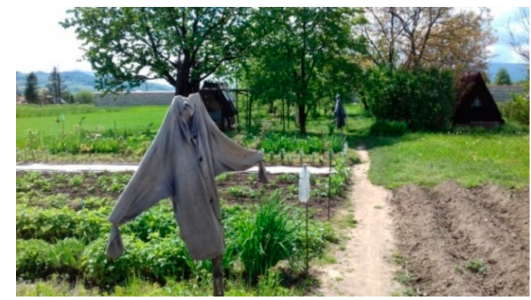

(b)

Figure 1. Location scarecrows in a vegetable garden $(\mathbf{a}, \mathbf{b})$ (Brzesko, Lesser Poland, Poland) (Source: Authors' own photographs.).

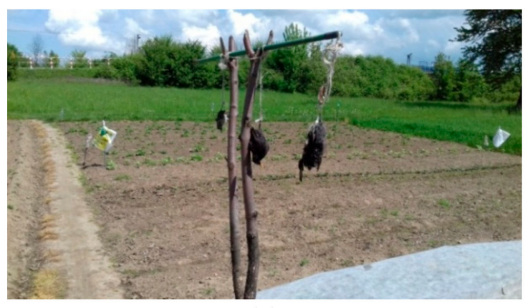

(a)

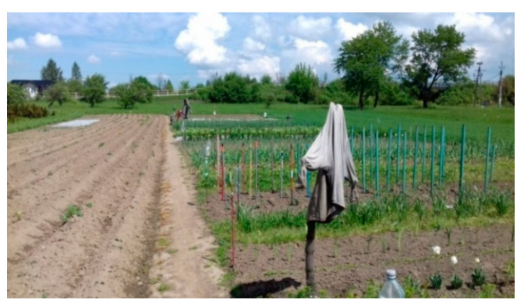

(b)

Figure 2. Dead birds hung up on a wooden frame (a) and a "scarecrow avenue" in a cultivated field (b) (Brzesko, Lesser Poland, Poland) (Source: Authors' own photographs.). 


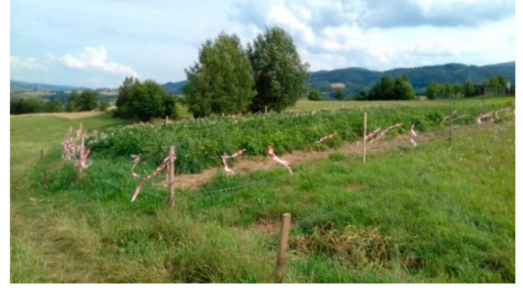

(a)

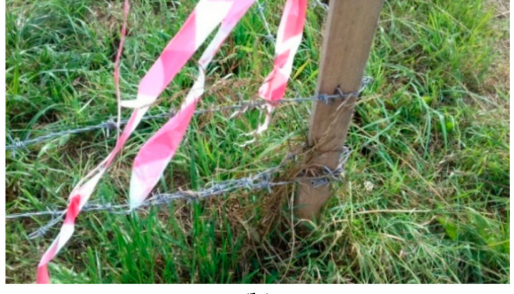

(b)

Figure 3. The application of plastic film strips (a) and a barbed-wire fence to protect vegetables (b) (Iwkowa, Lesser Poland, Poland) (Source: Authors' own photographs.).

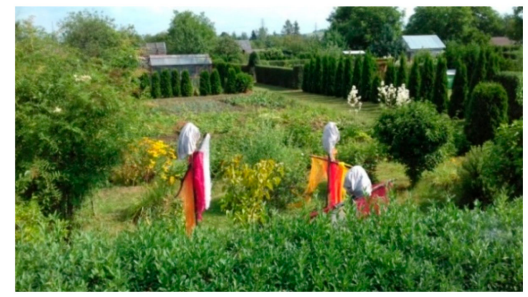

(a)

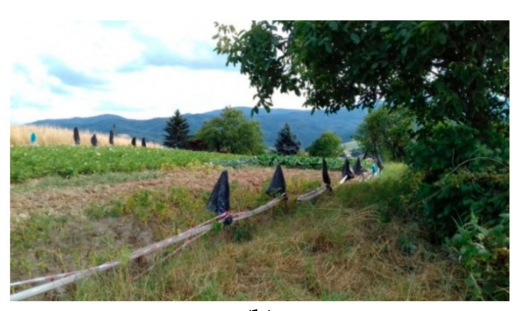

(b)

Figure 4. Scarecrows "guarding" vegetable gardens (a) and "plastic film deterrents" in a field full of vegetables (b) (Iwkowa, Lesser Poland, Poland) (Source: Authors' own photographs.).

In the early Native American cultures, people used scarecrows in the crop fields. Before the European emigrants arrived in North America, native adults would sit on the elevated stands to shout at birds or ground animals when they drew near the crops. Some native tribes even discovered they could soak corn seeds in a poisonous herb mixture to deter birds away. Moreover, many Native American children in the Southwest areas had performed contests to make the most frightening scarecrows. The Zuni tribe used lines of cedar poles strung with cords and animal skins to keep birds away from their crops.

As waves of immigrants came from Europe to North America, they also continued adopting scarecrows in their crop fields. German settlers in Pennsylvania brought with them the bootzamon or bogeyman to stand guard over croplands or orchards. Scarecrows became particularly popular during the period of America's agricultural development. After World War II, farmers in the United Statessprayed pesticides, such as DDT, on their crops and fruits to accomplish much more results. They identified that pesticides were actually bad for human health. Although we do not currently see many scarecrows guarding fields, theyhave become very popular fall decorations [34].

\section{Stories, Legends, and Customs}

More than 2500 years ago, the Greeks worshipped the god Priapus who, according to mythology, protected fields of wheat and grapevine crops. According to one of the legends, Priapus was a son of Aphrodite and Dionysus, the god of fertility, wildlife, grapevine, and wine. However, he was so ugly and misshapen that he was carried up a high hill and left to die there, although the child, found by the vineyard, managed to survive. Priapus liked playing in the vineyard since he was small. It was found that while he was there, no birds were approaching, which led to the conclusion that the boy deterred them. Therefore, he was encouraged to spend time in the vineyard, which resulted in abundant harvests of grapes. The rumour spread quickly and the Greeks began to carve wooden figures of the boy and place them in the vicinity of plantations in the belief that the crops would be more abundant. The Romans took over a significant part of the Greek culture and when their armies occupied what would become present-day France, Germany, and England, the custom was transferred there along with the belief in the effectiveness of a Priapus' effigy in the protection of crops [26].

Approximately 2500 years ago, the Japanese began to establish rice plantations that needed to be protected against birds and wild animals. It was a common practice at that time to stack piles of 
rags mixed with meat waste and seafood residues, which were subsequently burnt. According to archival records, the stench was so intense that it kept birds and wild animals at bay. Such a form of the "scarecrow" was called "kakashi", which means "a foul odour". Colourful fabrics cut into strips fluttering in the wind, or items glistening in the sun were also used at that time. The name, however, remained the same. Any form of animal deterrence was referred to as "kakashi". Japanese farmers also used scarecrows that took on a human form. They were mostly made of wood, and their clothes were stuffed with straw [26].

As recently as the 20th century, in Pennsylvania, farmers from Germany tried to protect their fields using a peculiar ritual: They passed the seeds, before sowing them, through a hole made in a bone of an ox. They believed that this would ensure protection against pest birds. Another ritual was performed as well in which three holes were dug out in the field corners. In the first hole, three seeds for birds were placed; in the second one, three seeds for caterpillars, and in the third hole, three seeds for beetles. This was believed to be a specific "gift for predators"; they were supposed to accept it and leave the crops intact. Moreover, in order to scare away birds and wild animals, gunpowder was used due to its intense and unpleasant smell, which was inconvenient for the vermin. Gunpowder was scattered onto small wooden boards coated with fat, which were then hung in a cultivated field. Gusts of wind would spread the odour all over the area. Farmers also used scarecrows that they called, "bootzamon". Their design was based on a wooden support frame, while the torso and the head were filled with straw. The outfit comprised trousers and a shirt or a coat. A wooden cap or a straw hat, old and worn out, wasplaced on the head. The joint between the head and the torso was occasionally covered with a red scarf. Another dummy was sometimes placed at the opposite end of the field. This was the colloquially called, "bootzafraw" i.e., the "scarecrow's wife", dressed in women's clothing. It was universally believed that she accompanied the "bootzamon" and helped him protect the plantation [26].

In the Polish lands, the belief in a variety of phantoms and frights used to be widespread for a very long time. This belief was founded on phenomena that could not be explained rationally at that time, and which inspired "terror". Mysterious characters could most often be found in old castles and palaces, abandoned manor houses, near old mills, at cemeteries, as well as in forests and on cultivated fields where they appeared as scarecrows [35].

There are rituals and symbols associated with scarecrows. In submontane areas and in the mountains, where land cultivation was particularly difficult, the scarecrow used to be set up with ritual solemnity. A farmer made the scarecrow at night and carried it outside as soon as dawn broke in order to prevent him from "having a spell put on by someone's eyes". Therefore, another name for the scarecrow was used, namely a "bogeyman". They were set up in the early spring and removed from fields in the autumn, after the harvest, to be obligatorily burned. Scarecrow burning was a ritual that celebrated the end of the hardship of seasonal cultivation work, and the smoke rising from a burning scarecrow implied a human soul flying away to the skies [28].

Sometimes farmers pass on funny stories, for example, onesuch story is about a tipsy peasant coming back from a fair, who noticed a farmer in a field and greeted him repeatedly in a loud voice. The farmer, however, failed to respond. The enraged peasant, who had too much alcohol, decided to teach a lesson to the rude farmer and correct his behaviour. He jumped at the man, threw him down to the ground, and pummeled him. Afterwards, he boasted to other villagers about how he taught manners to that farmer. Meanwhile, it appeared that the victim of the battery was a fashionable scarecrow, that the protagonist failed to notice while under the influence of alcohol.

The first strawmen to grace a village every year were the colloquially called, "Smigus strawmen". Since time immemorial, strawmen used to be set up on the Smigus night, which is the night between Easter Sunday and Easter Monday. They were placed by bachelors near houses where pretty maids lived. The strawmen were previously prepared, in the Holy Week or even before Palm Sunday. It must be noted that it was not easy to set up a strawman as it was hung from a tree or roof ridge, or placed in another visible place near the house. For every bachelor, it was a point of honour to set up a strawman 
on the Smigus night. A strawman located near a house indicated that bachelors were interested in the maids from that farm, while the absence of a strawman indicated that the maids were not popular with boys. This custom aroused a lot of emotion. On Easter Monday, early in the morning, all maids ran out into the field to look out for scarecrows. The interest in this custom was enormous. Villagers looked around, scanned homesteads and counted strawmen hung on trees and placed on fences, as the more strawmen could be seen, the more bachelors were interested in a particular maid, which was a reason to be proud back then. The elderly people used to make fun of it, however: "well, so they have set up three Smigus strawmen for the maid, so what? There is still no chance of getting married, however. When a bachelor is keen on a maid, not even a Smigus strawman is needed; it is just going to turn out successfully without the strawman" [27].

Most strawmen emerged in fields in May. They guarded vegetables from the moment they were sown. They were prepared a bit earlier, and they usually were paid a lot of attention as every farmer wanted to create the most beautiful strawman possible. Nobody set up flimsy or improperly made strawmen, as it was a disgrace that gave rise to malicious comments expressed by villagers. Field strawmen were always made of old clothes; therefore, they were "textile strawmen". Usually, they were made to resemble a boy. A properly crafted strawman was dressed from head to toe. A field strawman was rarely left "barefoot". Trousers and ajacket or sweater were stuffed with straw or, alternatively, hay. The strawman wore a cap, hat, or beret on his head. His neck was tied with a tie, scarf, or another adornment. A bag, a cane, a pitchfork, or another tool would be put in his hand. After the mission was complete, the strawman was either loaded on a cart and brought to the farm or burnt on the spot.

In Iwkowa (commune of Iwkowa, Lesser Poland, Poland), the strawmen were distinguished from scarecrows. The scarecrows were less smart. Only two poles and some old rags were needed to construct the scarecrow. The poles were nailed together to form a cross. Strawmen were deceptively similar to a human, while scarecrows shoddilyevoked feelings of misery.

In the vicinity of houses, as well asin orchards and farmyards, the house strawmen would be set up. While the field strawman was always the most elegant, the house strawman used to be a bit less ostentatious and usually took on the form of a scarecrow. Its main task was to deter pest birds, because until recently, apples, plums, pears, sweet cherries, common walnuts, and other fruit trees used to be commonly planted in the farmyard. Strawmen and scarecrows were often erected between sweet cherry trees, because cherry strawmen only had the upper part of the torso that was adorned with glittering ribbons and pieces of string. On farms, guardian strawmen were also distinguished. These guarded chickens, as well as ducks and turkey nestlings, primarily against crows. A guardian strawman was taller than a field strawman, ethereal, slim, and light. When farmers took over the care over nestlings, the strawman was concealed. The guardian strawman was placed in a different location every day, and the components of his outfit were changed in order to mislead birds [27].

In addition to the role of a field guard, the scarecrow also fulfilled an unspecified, additional function of a magical and ritualistic character. The scarecrow is a kind of remnant of old pagan superstitions that survived generational changes and progress, as Jan NepomucenKurkiewicz, an artist and photographer from Kraków, wrote about scarecrows [28]. The scarecrow is the "true king" that can unite and divide fairly by giving a little for animals to eat, while leaving the rest to the farmer. It is the "most beautiful king of the cultivated field".

\subsection{Scarecrows of the 21 st Century}

The traditional scarecrow standing in the field is certainly a graceful decoration that symbolises the arrival of autumn, but from a more practical perspective, it has become a relic of the past. Birds quickly become accustomed to a stationary dummy and start to ignore it as something that poses no threat. Therefore, traditional scarecrows have been replaced bythe products of modern technology.

In recent years, many new devices of scarecrows have been invented and adopted in the United States' rural landscape. A peregrine falcon, which is equipped with a remote-controlled 3D-printed 
raptor robotic bird, can swoop and soar to frighten real birds. The sonic bird cannon craftily plays the sound of shotgun blasts to signal imminent danger for many birds. The raucous explosions are broadcasted by digitised recordings of specific bird distress calls. There are also high-tech motion-driven models that hurl water at any intruder that strays onto the territory. There is also a hawk-like drone that features a GPS-guided autopilot mode, which can be programmed remotely, patrols a sprawling property, and generates a deafening whir. The drone has a built-in megaphone to broadcast distress cries and predator calls to fright intruders. The solar-powered scarecrow with its long twin wings spins around to scare away prowlers. In addition, the solar-powered robot wolf is designed to scare wild boar, deer, and other animals [36].

\subsubsection{High-Tech Scarecrow}

A digital scarecrow, which is a solar-powered robot designed by KyungRyul Lim and MiYeon Kim has a "digital eye" equipped with an infrared sensor that observes a cultivated field within a 178,000 square foot range. Spread out arms is the only thing that the digital scarecrow has in common with his "analog" counterpart. The inventors assure that the compact design and a movable stand enable the device to be quickly and easily repositioned. When the infrared-sensitive eye detects the presence of a bird or another animal, the robot emits a series of ultrasound waves in order to deter them [37]. However, a futuristic-looking robot placed in a cultivated field can be perceived as an envoy of an alien civilisation that is just creating another, somehow "famous" crop circle, especially after dark. It can be easily stolen as well; while the digital scarecrow keeps an eye on the crops, there is nobody to protect the scarecrow from thieves.

Another example of modern bird deterrence is the solar-powered mechanical bird-scarer known as the California ScareCrow (manufactured by CropGuard Inc.). The body of the ScareCrow is powder-coated making it rust-resistant and maintenance-free. The span of the "arms" of the device is 34 feet; they remain in constant motion, and red and silver mylar strips are attached to them. The rotation of the arms is clockwise and counterclockwise at different intervals to ensure that the birds cannot time the on-off action as they do with other deterrents. The device is equipped with batteriesto ensure that it can operate on cloudy days as well.

\subsubsection{Laser Scarecrows}

In late summer and autumn, a hectare of broadleaf cattail on a marshy ground dominated by this plant can accommodate up to 1500 blackbirds. Therefore, even small marshy grounds with an area of 5-10 hectares, which become "poultry houses" of sorts, can cause serious problems for sunflower producers. Laser devices with a red and green beam, such as Avian Dissuader lasers (manufactured by Feather-Light Technologies LLC, Louisville, Kentucky), are efficient in scaring birds away. The "bird disperser" has a power classification that places it in the IIIb laser category. A red laser has a power output of 50 milliwatts, while a green one of 30 milliwatts. Study results demonstrated that laser beams efficiently deterred blackbirds [38].

Laser scarecrows also appear to be effective as a means of preventing starlings and blackbirds from feeding on sweetcorn on fields. According to breeders' reports, they are more effective than repelling birds with scare guns. Commercial laser scarecrows are more expensive than cannon repellers, but they cost less to use and help avoid noise issues [39]. Scarecrows can effectively protect crops against Canada geese as well. However, "Laser scarecrows" are not effective in deterring deer and other mammals [40].

Mechanical engineering students from the University of Victoria in British Columbia have designed a laser scarecrow to be used mainly at night when no cannon repellers or scare guns can be used. Study results indicated that a green laser with a lower power output was the most efficient in scaring Canada geese away. The deterrent device is placed on a stand, at a height ranging from 12 to 15 feet above the ground, and fires a laser beam within a pre-programmed area. To prevent interference with aircraft, the device is designed that the laser beam does not exceed the horizon line. 


\subsubsection{Smart Scarecrow}

Most technologies used to scare birds have not been successful at keeping birds away because species tend to habituate to devices, such as propane-powered cannons, which produce loud noises [41]. Moreover, birds quickly learn that playback of predator vocalisations, or conspecific alarm or distress calls, do not pose a real threat if there is no negative reinforcement paired with the stimuli [42].

A computer system that deters birds has been developed in Thailand. An intelligent scarecrow was designed using an image processing technique. The system was designed to detect pests in video frames in real-time. Whenever birds are detected, a loud sound is generated. The system consists of four major components: (1) Image acquisition, (2) image preprocessing, (3) bird recognition, and (4) generating sound [43].

Birds are a nuisance to farmers, but they can also pose a serious hazard to aircraft. In order to help clear the runway, deterrent systems, such as the Scarecrow Bio-Acoustic (manufactured by Ultima) in the form of a touchscreen tablet are used. The system includes loudspeakers that are mounted on the vehicle roof and emit piercing sounds that scare birds away. The system has a built-in ornithological guide to help it identify the most common species, while the GPS system tracks the exact location of birds.

Other systems emit a continuous sound at a constant volume, which limits birds' ability to listen out for the sounds emitted by nature and predators. Birds tend to leave this kind of an environment in search of a safer place. This was confirmed by research conducted at airports where the use of a sonic network resulted in a significant reduction in birds' activity [44].

An alternative or supplement to sound deterrent systems include cannon repellers. The Scare Wars System gas cannon (manufactured by Reed-Joseph International Company) generates noise with a sound level of $130 \mathrm{~dB}$, and operates on a 5-gallon propane tank. The gun is solar panel-powered and programmable, with various settings allowing it to fire at any location with a duration ranging from 30 $\mathrm{s}$ to $20 \mathrm{~min}$.

\subsubsection{Three-Dimensional Decoys}

In order to deter birds and wild animals, predator decoys are used as well. RoBird (formerly Clear Flight Solutions) is the creator of the RoBird UAV, a remotely piloted robotic Peregrine Falcon. This UAV (unmanned aerial vehicle) is the most effective bird control solution in the world, because it does more than just scare birds. It is the only tool available that can also 'lure' birds away and 'herd' flocks in any direction. RoBird is an ornithopter, achieving lift and propulsion by flapping its wings and steering with tail flaps. This unmanned aircraft is launched by an observer or secondary pilot when in full throttle and remotely operated by the pilot on the ground. The RoBird offers a reliable, manageable, safe, and humane way to help reduce bird populations. Birds recognize this UAV as a true predator. It is the combination of its flying technique and the silhouette of an apparent predator that makes it successful at bird hazing [45]. Contrastingly, the "3D Coyote" is a coyote decoy in an attack pose. These predator replicafrighten geese, birds, and other small pests away from open outdoor areas. The 3D structure makes the decoy visible from every angle, making it more effective than a traditional coyote silhouette cardboard cutout. Its moving fur tail highlights its lifelike presence. Wind causes the tail to move in the wind, increasing efficacy. It can also be effective at much longer ranges than sound machines, since bird vision is generally strong and can spot predators at great distances. In this case, however, the effectiveness of the decoy is determined by its regular adjustment.

\subsection{Who Cares about Scarecrows?}

Scarecrows are a disappearing feature of the rural landscape [9]. They will probably soon appear only in fairy tales and open-air ethnographic museums. Scarecrows are increasingly less commonly found in cultivated fields, and more frequently in museums, even though they are still deeply rooted in the consciousness of local communities and become the leitmotif of a variety of initiatives. 
In the village of Sołonka, commune of Lubenia (Podkarpackie Voivodeship, Poland), a unique Scarecrow Museum is found. There are several dozen scarecrows exhibited at the museum. The Museum was established in 1985 on the initiative of Aleksander Bielenda. The museum in Sołonka annually records a few thousand visitors from across Poland and abroad. The custodian shares his ethnographic and historical knowledge with them with passion. Moreover, in Lubenia, there is a nature/ethnographic/historical route set out based on the local tradition and folk rituals as well as the history and culture of the village, with an emphasis put on the peculiar agricultural ritual of constructing and setting up the scarecrow. The route was named "The Nature-Ethnographic-Historical Highway of Scarecrows". The trail is $2 \mathrm{~km}$ long, and mostly runs along field paths. A part of the route goes along the baulk that separates fields and strips. Along the whole length of the trail, numerous scarecrows are on display. Notably, the strawmen are also sign-posts and were built by the trail originators themselves by hand.

Scarecrows also have their "holidays". Until 2005, "Fright Fest" (Polish: Straszydlisko) was organised from the initiative of the museum in Sołonka during the autumn in various villages of the Subcarpathia. This event had an international range as it was "visited" by scarecrows from Ukraine and Slovakia. Moreover, in the village of Rudzica (Śląskie Voivodeship, Bielski District, commune of Jasienica, Poland), The Scarecrow Day has been celebrated on an annual basis for almost 30 years. During the celebration, a competition called, "The Most Interesting Scarecrows" is held. Both the competition and the Scarecrow Day are organised by the Communal Cultural Centre in Jasienica and Florian Kohut, a painter [46]. In Rudzica, there is also a Florian Kohut's private gallery "Under the Scarecrow" that exhibits a variety of scarecrows, some of them even 20 years old. Similar competitions are held at other locations in Poland. At the Grabski Agricultural School Complex in Sędziejowice, a competition named, "We Greet the Spring with Cheerful Scarecrows" is organised. A peculiar scarecrow gallery is also located in Olsztyn n. Częstochowa. The gallery was established by Stanisław Brzezina Kałkus, the founder of Jurajski Teatr Stodoła. In this way, local artists supplemented the exposition presented to tourists in a renovated cottage, called "WójtówkanaZakolu" (a local museum in Olsztyn in Ślaskie Voivodeship), which reflects the nature of a typical Olsztyn farm from the previous century. Moreover, the Wójtówka Na Zakolu is a place where events are held intending to continue folk traditions and culture, which intensely support the development of rural tourism, including agritourism farms [47].

Scarecrows have their "holidays" in other countries as well. As part of the Wray Scarecrow Festival (usually held in May in the village of Wray, Northern England), villagers create scarecrows themselves by hand, and then exhibit them in their own gardens, mostly in front of the house. At the time of the festival, scarecrows are scattered throughout the area of the village, and are more of a tourist attraction than scarers of wild animals [48]. A different example is the Stevensville Scarecrow Festival (Ravalli County, MT, USA). Original scarecrows are made by local companies, clubs, non-profit organisations, families, and children. During the festival, the spectators vote to choose the most attractive scarecrow. The festival is an event aimed at integrating members of local communities. Another example is the Little Sutton Scarecrow Festival (Cheshire, England). The idea for the scarecrow festival arose on the initiative of the members of local communities belonging to the PALS (Positive Action for Little Sutton) organisation. The inhabitants of Little Sutton and the neighbouring localities are invited to join in the fun, make a scarecrow, and exhibit it at the festival. The PALS group has developed a web application, and anybody who has made and set up a scarecrow can plot its location on an interactive map that is accessible to visitors via the Internet. Another event that is held on an annual basis is the Garstang Scarecrow Festival (Lancashire, England). In 2019, the leitmotif of the festival was the slogan, "Heroes and Villains". In Cleveland (OH, USA), the East Cleveland Scarecrow Festival is organised. This is a family event with the aim to unite members of local communities in the process of joint building a scarecrow. Another example is the Wistow Scarecrow Festival (Wistow, Leicestershire, England). The first edition of the Festival was held in 2009. Every year, the festival has a different leitmotif. 


\section{Materials and Methods}

Studies on the roles of cultural heritage items in regional development are usually case studies focusing on specific types of cultural heritage or individual regions [49-52]. Research often involves interviews with members of local communities, leaders, or representatives of selected focus groups [53, 54]. One of the restrictions of this approach is that results cannot always be extrapolated to provide general conclusions because they are based on a specific region [20]. However, this is not always the case. Some units are exceptional, representative of their region and insights into them may facilitate broader conclusions.

To make the study more relevant and improve the results and conclusions, it was designed as a case study evidence-based research [55]. The study involved Iwkowa and Brzesko, the Małopolskie Voivodeship (Figure 5), which are hierarchical centres on multiple plains, including transportation, the economy, and society $[52,56]$. Brzesko is the focal point of transit and personnel car traffic of central Lesser Poland between prominent regional hubs, Kraków and NowySacz. It affects Iwkowa situated not far from Brzesko. Moreover, because of good transport links with the Kraków agglomeration, within the city is where many residents of the two smaller locations work. Farming activities are being displaced by services, including tourism and commerce. These circumstances significantly affect social, economic, and cultural changes.

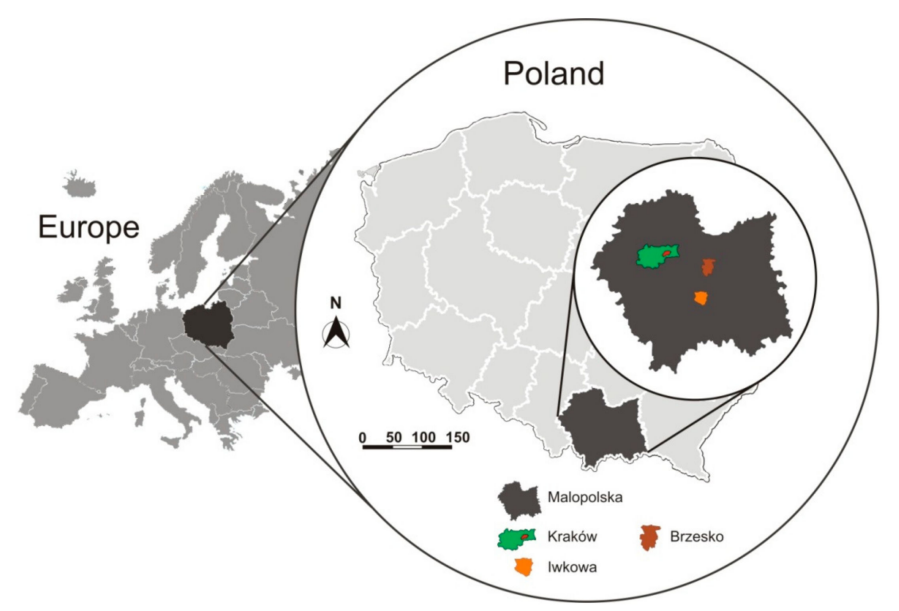

Figure 5. Location of the Brzesko and Iwkowa communes in relation to the city of Kraków (Lesser Poland, Poland) (Source: Authors' own work.).

The study used the photographic documentation and diagnostic survey method, and applied the structured direct interview technique. Interviews were carried out with local community leaders who were selected for their good knowledge of the commune and the social character of the activities they pursue. These people have frequent contact with the commune inhabitants, and are familiar with the problems of local communities.

The questionnaire included questions concerning the respondent's profile, open questions, closed questions related to wild animals' activity in the commune, and to the perception and use of scarecrows and modern methods for scaring wild animals away by the inhabitants of communes currently and in the past.

Brzesko is an urban and rural commune located in the central part of Małopolskie Voivodeship, in Brzeski District. The commune is located on the Uszwica and Uszewka rivers, right-bank tributaries of the Vistula, and on the boundary between the Sandomierz Basin and the Wiśnickie Foothills. It covers an area of $103 \mathrm{~km}^{2}$, of which the town area is $12 \mathrm{~km}^{2}$. There are 36,342 inhabitants registered in the commune, of which 17,090 in the town and 19,252 in rural areas. Within the administrative boundaries of the commune, there are the town of Brzesko and nine villages: Bucze, Jadowniki, Jasien, Mokrzyska, Okocim, PorębaSpytkowska, Sterkowiec, Szczepanów, and Wokowice. In 2014, most of 
the Brzesko commune dwellers (almost 53\%) were inhabitants of the rural area. Of the nine villages in the commune, the largest one in terms of population is Jadowniki, where approximately $14 \%$ of the commune dwellers live, while the smallest population is noted in Wokowice where only $1.4 \%$ of the commune inhabitants live. The population density in the commune was 354 people per $\mathrm{km}^{2}$.

The commune of Iwkowa is a typical rural commune in Małopolskie Voivodeship and the southernmost part of Brzeski District; it borders Nowosądecki, Limanowski, and Bocheński Districts. The area of the Iwkowa commune is quite diverse because it is located at the interface between two physiographical regions, the eastern edge of the Island Beskids and the western part of the Rożnowskie Foothills. The picturesque Iwkowska Valley stretches out in the middle. In terms of transport, the commune of Iwkowa is located approximatelyeight kilometres to the west from the national road from Brzesko to NowySacz, opposite the Czchowskie lake. Iwkowa is a small commune with an area of 47.2 $\mathrm{km}^{2}$ and a population of slightly over 6000 .

\section{Results}

A total of 15 in-depth interviews were carried out, eightin the Brzesko commune and sevenin the Iwkowa commune. The interviews were carried out with the commune employees and authorities, employees of selected public utility institutions, and local community leaders (Table 1).

Table 1. Characteristics of respondents.

\begin{tabular}{|c|c|c|c|}
\hline Age Range & Functions Served & $\begin{array}{l}\text { Educational } \\
\text { Background }\end{array}$ & $\begin{array}{l}\text { The Area of Cultivated } \\
\text { Land Owned (ha) }\end{array}$ \\
\hline \multicolumn{4}{|c|}{ Brzesko commune } \\
\hline $50-60$ & $\begin{array}{l}\text { Chairperson of the Local Action Group } \\
\text { Association "KwartetnaPrzedgórzu" } \\
\text { Chairperson of the Country Housewives" }\end{array}$ & Master's degree & 1 \\
\hline $50-60$ & $\begin{array}{l}\text { Association in Jadowniki; instructor at the } \\
\text { Municipal Cultural Centre }\end{array}$ & secondary technical & 0.5 \\
\hline $50-60$ & $\begin{array}{l}\text { Chairperson of the Union of Polish Teachers } \\
\text { in the district; head of the Regional Group } \\
\text { 'KrakowiacyZiemiBrzeskiej' }\end{array}$ & Master's degree & N/A \\
\hline$>60$ & $\begin{array}{l}\text { President of the Volunteer Fire Service in } \\
\text { Wokowice; President of the Board of } \\
\text { Volunteer Fire Service Communal Division }\end{array}$ & mechanical technician & N/A \\
\hline $50-60$ & $\begin{array}{l}\text { Szczepanów Village Leader; Brzesko } \\
\text { councillor }\end{array}$ & Commodity technician & 0.37 \\
\hline$>60$ & $\begin{array}{c}\text { Head of the Song and Dance Ensemble } \\
\text { 'Porębianie'; Chairperson of the Country } \\
\text { Housewives' Association }\end{array}$ & agricultural technician & 0.2 \\
\hline $50-60$ & $\begin{array}{l}\text { Elective member of the local government; } \\
\text { Brzesko Commune Deputy Mayor }\end{array}$ & Master's degree & 0.3 \\
\hline $30-40$ & Brzesk Municipal Council employee & Master's degree & 0.5 \\
\hline \multicolumn{4}{|c|}{ Iwkowa commune } \\
\hline$>60$ & $\begin{array}{l}\text { Conservator of a local historic church in } \\
\text { Iwkowa on a wooden architecture trail }\end{array}$ & $\begin{array}{l}\text { vocational (construction) } \\
\text { education }\end{array}$ & 0.1 \\
\hline $30-40$ & $\begin{array}{l}\text { Commune Official for local government } \\
\text { affairs (promotion, tourism, etc.) }\end{array}$ & Master's degree & 0.3 \\
\hline $50-60$ & Iwkowa Commune Head & Master's degree & 5 \\
\hline $40-50$ & Iwkowa Public Library employee & Master's degree & 0.01 \\
\hline $50-60$ & $\begin{array}{l}\text { An accountant at the Iwkowa Commune } \\
\text { Office. Agritourism farm manager }\end{array}$ & Master's degree & 1.5 \\
\hline $30-40$ & $\begin{array}{c}\text { Eco-advisor at the Iwkowa Commune } \\
\text { Office }\end{array}$ & Master's degree & 6 \\
\hline $30-40$ & $\begin{array}{l}\text { Cultural manager at the Communal } \\
\text { Cultural Centre }\end{array}$ & Master's degree & 0.03 \\
\hline
\end{tabular}


All respondents unanimously agreed that wild animals posed a threat to cultivated fields in both Brzesko and Iwkowa communes, with nine respondents pointing out that in recent years, the destruction of crops by wild animals had significantly increased. Twelve respondents conducted agricultural activities on a different scale, including the cultivation of potatoes, cereals, vegetables, orchard fruit, and grapevines. Respondents reported high activity of wild boars, roe deer, foxes, moose, and birds. Therefore, farmers made attempts to protect their crops by the application of various remedies. Respondents indicated that the remedies most commonly applied in the communes concerned at that time included: (a) Covering crops with non-woven, non-fixed interlining; (b) the use of barbed-wire and electric fences and, where possible, masonry or metal fences; (c) reducing the population by controlled culling carried out by hunting clubs; (d) the use of noise-emitting cans, rustling ribbons, and acoustic deterrence methods, such as the playback of recorded noises of predatory animals like the goshawk; (e) chemical methods, such as pouring chemical agents or natural deterrents like nettle infused water into burrows; (f) making bonfires, leaving sources of light in the field; (g) acoustic deterrence using pyrotechnical materials, firecrackers, calcium carbide, etc.; (h) the introduction of predatory animals like the kestrel into the areas frequented by pests; (i) setting up scarecrows in the field; (j) the use of hunting or defense dogs. Respondents also mentioned other, less common ways to deter wild animals, including scattering hair obtained from local hairdressers over fields, lighting grave candles at night, or burning old tyres. At the same time, respondents pointed out that in the past, scarecrows were commonly used. Dead birds were also hung up in the field, not only with their heads down, but also in the flying position. Firecrackers and other sources of sound were also commonly used, including bottles, aluminium cans, and pieces of plastic attached to posts inserted into the ground. Bonfires were made as well.

Every third respondent declared the use of scarecrows (fivepeople). Ten respondents claimed that scarecrows were used by farmers and could be found in the communes under study. The main argument put forward by respondents against scarecrows is their ineffectiveness. All respondents, including those who used scarecrows, declared that they were ineffective or not very effective. All respondents claimed that wild animals were not afraid of scarecrows. Respondents claimed that "new", more effective forms of protection were used at that time, for example fences, including electric fences, protective nets, and acoustic deterrent devices. At the same time, respondents made an equivocal request for increasing the frequency of wild boar culls by hunting clubs, in particular in the commune of Brzesko where wild boars cause significant damage to the extent that their activity results in the disappearance of agricultural activities in the commune.

Respondents consistently described the scarecrow:

- The scarecrow takes on the form of a human figure. He is dressed in worn-out clothes. His task was to deter animals: "he was banging and rustling".

- Two poles nailed together to form the shape of the cross, rammed into the ground. A head of straw donning a hat. The whole was covered with a worn-out shirt, filled with straw to give him the human shape, and tied around with a worn-out belt or a piece of rope. Placed in a cereal or maize field, their task was to deter birds.

- Two poles nailed together to form a cross, wrapped in rags and crowned with a hat. They were primarily used to scare birds away.

- Two rods or poles nailed together to form a cross- "movable and rustling".

- A friendly figure remembered from childhood when parents used to set him up in a cultivated field. He triggers positive associations since its task was to protect crops against pests.

- The scarecrow is made of a "pole" stuck into the ground, on which old rags and aluminium cans filled with stones are hung. They are supposed to produce sounds in the gusts of wind.

- Two poles nailed together to form a cross, on which worn-out clothes and noise-producing objects have been hung. 
- A figure made of planks nailed together, dressed in old rags. He usually wears a hat. Farmers use scarecrows in the belief that they will fulfil their function.

- The scarecrow deters pests, primarily birds. Scarecrows were used in the cultivation of millet but this crop is no longer grown. Used to protect grapes against sparrows. The scarecrow is made up of old clothes, straw, a hat and a belt, in the fashion of a human.

- The scarecrow is an element of agricultural landscape. His task is to deter animals, but he is not very effective.

- Scarecrows have always been associated with agriculture; they scared birds away. The scarecrow, dressed in a shabby old coat, was designed to rustle and swing in the wind.

- The scarecrow is a puppet, a wooden cross, a hat, and small bells. An item of red was used to protect against spells and ensure an abundant harvest.

- The scarecrow is intended to scare animals away. He is made of crossed poles, dressed in old clothes and a hat; it is difficult to determine whether he is effective.

- Sometimes they are found in cultivated fields where they are set up with the intention to deter birds. Scarecrows are most commonly used in small farms.

Respondents mentioned the main reasons why scarecrows were no longer used:

- They stand in the field and scare "passers-by lost in thought" more than animals, which are no longer afraid of humans. Scarecrows are rare because there are fewer and fewer cultivated fields.

- Scarecrows are sometimes placed in a field, as "something needs to be moving in the field, which keeps animals at a distance". The scarecrow, however, has limited effectiveness because animals get accustomed to him. Scarecrows fail to fulfil their function because "the wild boars are not scared of them".

- Fewer and fewer scarecrows are currently erected since they are ineffective. More effective methods, e.g., putting up fences, are applied. Animals are not afraid of scarecrows. In addition, scaring sound devices that emit loud noises, shots, or explosions as well as mechanical, metal, or revolving scarers are used.

- Scarecrows are not used. Other methods of repellence are not employed either as cropland has disappeared. Large wild boar population and unprofitable agricultural production have resulted in the abandonment of crop cultivation. The only form of protection against animals is fencing that needs to be additionally reinforced, and a controlled reduction in the population.

- The area of land under crops has significantly decreased. Furthermore, there are fewer birds, in particular sparrows, and more wild boars that are not afraid of scarecrows. Only coniferous trees are left in forests. There are no oak trees and therefore, no food for wild boars that look for it in cultivated fields and home gardens. At the same time, wild boars are not afraid of noise, dogs, or humans. They are intelligent and adapt quickly. Only solid fences are sometimes effective.

- Scarecrows are seldom used as there are few fields under crops. Scarecrows are found more often in the old part of the village.

- Scarecrows are used, but there are fewer of them. The tradition of erecting scarecrows is disappearing. However, in certain families it has been continued for generations: "the scarecrow should be there, even if he is not very much effective". Before, scarecrows used to be commonly found, and they were made with care.

- In the days of old, each farmer made scarecrows himself. Older people still set up scarecrows with the conviction that they fulfil their role. However, there are increasingly fewer scarecrows: "there are fewer cultivated fields, therefore there are fewer scarecrows". Wild animals are not afraid of them".

Only two respondents were aware of legends, rituals, beliefs, or customs associated with scarecrows: 
- "Tramps" (as scarecrows used to be called in the commune of Iwkowa) were tied up to a tree at night, usually on Easter Monday, near the house of a farmer who had a marriageable daughter. "Tramps" were hung up in locations where there were maidens enjoying bachelors' interest. Therefore, it somehow enhanced the farmer's prestige.

- In the days of old (a term used to refer to the post-war years until the end of the 20th century), there was a ritual of setting up the so-called "bogeyman". This was a way of putting a spell. The "bogeyman" was a "malicious character" tied in a growing cereal crop; the ritual involved weaving a human figure in living cereals. The task of a farmer who has noticed the "bogeyman" in the cereal field was to untie or unknot it. There was a superstition that if the farmer had failed to do so, a misfortune, e.g., crop failure, would have befallen the farm.

- According to old beliefs, the scarecrow should be adorned with a red ribbon or any other red item, e.g., a feather stuck in the hat, or a scarf wrapped around his head. The item of red was supposed to counteract the so-called "spells".

A specific "peculiarity" practised to this day in the commune of Iwkowa is scattering cut human hair over cultivated fields. Commune inhabitants visit their local hairdressers to collect cut hair; then they scatter it over fields. This is very popular, to the extent that reservations are made at hairdressing salons for the collection of cut hair.

\section{Discussion}

The commune of Brzesko has, for several years, been struggling with the problem of damage caused by the growing wild boar population. Culls carried out by hunting clubs are obstructed by environmental organisations. The losses caused by wild boars' activity are of such high significance that many farmers have abandoned farming for this reason. No forms of deterrence are of help. The efficiency of chemical, acoustic, and odour repelling methods is limited in time. Therefore, respondents indicated a reduction in the wild boar population to be the only effective way of dealing with the problem.

Local community leaders felt no sentimental attachment to the scarecrow. The scarecrow is not particularly well-rooted in the culture and ceremonies of the Iwkowa and Brzesko communes (Lesser Poland region). The oldest inhabitants continue the tradition of setting up the scarecrow because scarecrows were commonly found in the countryside when they were growing up. This is more associated with a habit than with a belief in their effectiveness.

The young and educated commune inhabitants do not use scarecrows. They feel no sentimental attachment to scarecrows. They feel no nostalgia and have no particular memories or associations related to scarecrows. Scarecrows have been stripped of their mystical aspect by science and technology. They are perceived only in terms of the effectiveness of their action. They have lost their mysteriousness, and no longer inspire respect or give a sense of dread. These days, the scarecrow is only "two poles wrapped in an old rag". Few people pay attention to him. There is no belief that he fulfils his function. Due to technological progress and education, the scarecrow has disappeared from beliefs and traditions. Furthermore, due to the territorial expansion of humans, animals have become less fearful. People are aware of scarecrows and know what they were used for, but currently treat them with reservations as part of old beliefs and superstitions.

In the respondents' opinions, agricultural production is disappearing in the communes concerned. Many fields are set aside, overgrown, and neglected, which is why they are overrun with wild animals. Forest game, in particular wild boars, are not afraid of scarecrows. These animals are, to a large extent, accustomed to humans, noise, and heavy traffic. Scarecrows are currently used at most to scare birds away, although respondents claimed that with larger flocks of birds, it was only helpful to cover fruiting plants.

A decrease in the area of agricultural (and orchard) crops has resulted in the disappearance of the scarecrow from the landscape. Large-scale farms do not use traditional scarecrows, while small family farms gave up agricultural production. Moreover, in the commune of Brzesko, there is no well-rooted 
tradition of setting up scarecrows in fields. The scarecrow is not rooted in the consciousness of local communities as something closely linked with a commune or agricultural production.

The Condition and Prospects of the Development of Agriculture in the Lesser Poland Region of Poland

Respondents unanimously raised the issue of agricultural production abandonment. The Lesser Poland understood as a region is distinguished by common historical heritage and similar economic and social characteristics and have faced a great challenge, the inevitable structural and social changes in rural areas and the adaptation of agriculture to the challenges of the 21st century. Similarly to other regions of Poland, agriculture in the Lesser Poland region has recently been undergoing continuous ownership and structural transformations.

The total area of agricultural farms in Małopolskie Voivodeship in July 2016 was 662,100 ha, which accounted for $4.1 \%$ of the area of agricultural farms in Poland. In Małopolskie Voivodeship, agricultural farms covered $43.6 \%$ of the total voivodeship area. Compared to data for 2015 , the area of land used in agricultural farms in Małopolskie Voivodeship decreased by $1400 \mathrm{ha}$, by $0.2 \%$. Of the total number of farms with agricultural land, $99.9 \%$ farms are maintained in good agricultural condition, while $72.6 \%$ farms cultivated field crops [57].

The characteristic feature of agriculture in Małopolskie Voivodeship is the significant farm fragmentation. In 2016, most farms, i.e., 36.9\% of all farms with agricultural land, cultivated 1-2 ha of them. Moreover, Małopolskie Voivodeship is distinguished by the lowest percentage of agricultural land compared to other voivodeships in Poland, in particular, the area under crops, and a high percentage of meadows and permanent grassland, orchards, home gardens, as well as forests and forest land [57].

The high agricultural structure fragmentation in Małopolskie Voivodeship limits the developmental possibilities of agriculture in this area. The districts located in the Western Carpathians and Carpathian Foothills are characterised by a significantly lower potential for the development of agriculture, which is contributed to by natural difficulties in carrying out agricultural production that increase the costs of conducting agricultural activities. This is also true for the analysed Brzeski District and the following districts: Gorlicki, Nowosądecki, Nowotarski, Tatrzański, Limanowski, Wielicki, and Olkuski [58].

Due to difficult natural conditions, the Brzeski District is classified to be one of the districts in the Lesser Poland region with a significantly lower potential for agricultural development. This leads to a gradual decrease in the number of farms conducting agricultural activity, particularly in the Brzesko commune. Modern production, an increase in the area of cultivated fields, and the driving of wild animals from their natural habitats have resulted in scarecrows no longer being used. In communes with no well-rooted and continued tradition of setting up scarecrows, their disappearance from the rural landscape will be determined by their lack of efficiency in action.

\section{Conclusions}

The tradition of setting up scarecrows is deeply rooted and has a significant symbolic meaning that is exceptionally extensive. The scarecrow used to be associated with the sphere of fertility and yield, but its figure was also linked to the veneration of the dead. The scarecrow is also an object of rural culture, and can sometimes be an original work of folk art. The erection of scarecrows in fields and gardens is part of old rural customs and rituals.

With the progress of civilisation, people's knowledge about the surrounding world has changed. In older times, nobody doubted the effectiveness of scarecrows; on the contrary, people even believed in their "magical powers". Contrastingly, few people currentlygive credence to the supernatural powers of a "man of straw" intended to deter birds or wildlife. The animals themselves changed as well. Due to progressive urbanisation and the development of infrastructure, wild animals have ceased to fear human settlements and the humans themselves. Therefore, even if a scarecrow scares a wild animal away on the first try, it will quickly get used to its presence. Scarecrows are thuscurrently set up by elderly inhabitants; not for reasons of efficiency, but as an element of tradition or as a way of spending 
free time with grandchildren. Moreover, no scarecrow-related rites are performed, mainly due to changes in the mentality of the rural populations and agricultural engineering.

Strawmen are gradually disappearing from fields, orchards, and yards. There are fewer birds as well. Fewer or no vegetables are cultivated either. In home gardens, it is difficult to find fruit trees as they have been supplanted by conifers, thujas, or ornamental shrubs. Where it is necessary to deter birds, colourful ribbons or plastic bottles put onto metal rods are used. Currently, the tradition of setting up Smigus, field, garden, or yard strawmen rarely continues. They have been replaced by plastic or plaster characters from fairy tales and comic books, and modern deterrent devices set up in fields.

While scarecrows were often made with passion and "had a soul", modern deterrent devices are nothing more than tools in farmers' hands. They have lost their mystical, ritualistic nature, and are just devices and machines designed to scare animals away effectively. Some of them even resemble the scarecrow, but usually in a factory-modified version. Such a scarecrow does not feel as if ithas a soul, only a set of battery-powered electronic controllers that are connected to a gas cylinder. If the traditional scarecrow could speak, he would certainly claim that in his opinion, modern deterrent devices are a kind of "cyborgs from the future".

Scarecrows represent with dignity the times when they fulfilled their duties. Modern scarecrows may have heads made of a football, wear leather jackets, and are adorned with aluminium cans and compact discs that glisten in the sunlight. The traditional rural image of the scarecrow that was indeed supposed to pretend to be a farmer in the course of fieldwork bears the stamp of the epoch. Moreover, scarecrows currently wear football team shirts and promotional gadgets of popular fast-food chains.

Modern scarecrows have changed drastically from the traditional straw body shape in the rural United States area. An upscale array of intimidating devices, like shapes of cats, raccoons, and other tricky creatures are currently more popular in the fields. Some contemporary scarecrows roar like thunder. Others prowl the skies, rumble, spew water, or simply look and act mean to scare the invaders. Many of such kinds of remarkable techno-scarecrows are developed and introduced in the present days.

Overall, scarecrows are an indicator of cultural changes in rural areas. These are the disappearing elements of Poland's rural landscape. Soon, they will probably appear only in fairy tales and open-air ethnographic museums. Scarecrows are less and less commonly found in cultivated fields, even though they still exist in the consciousness of local communities. As late as the end of the 20th century, the custom of setting up the scarecrow was followed in Poland, and scarecrows were commonly seen in the rural landscape. They protected fields against birds, wild boars, roe deer, hares, and other animals. Currently, this custom is becoming forgotten and is regarded as a "curiosity from a bygone age". Scarecrows are currently used in the analysed communes only by older people who continue this tradition that is, however, no longer passed on tothe next generations. Younger people do not use scarecrows because they believe they are not effective. The scarecrow has been stripped of its former dignity, and deprived of its position of the "king of cultivated fields". The fact that scarecrows are no longer used has been due to the economic calculation and cultural changes; the scarecrow is no longer a mysterious figure that guards the farm, and has become "two crossed poles wrapped in old rags that do not serve their function anymore".

The status of a cultural heritage asset is not set in stone. A cultural heritage asset of one generation does not necessarily have to be considered valuable by future generations. They may reject the cultural heritage of their ancestors. Some signs of this state of affairs are evident in Poland. The scarecrow, a part of cultural heritage for older generations of Poles, is just a straw figure with no practical purpose or cultural meaning for new generations. If the memory of the scarecrow is not preserved and nurtured, it will no longer be seen as a cultural heritage asset in Poland. The traditions related to the making of the scarecrow and delivering it to the field will be lost. Legends and beliefs will be forgotten.

Author Contributions: K.K. compiled and analysed the relevant literature, carried out surveys, and processed survey results, as well as conclusions. R.K. drew up the description concerning the USA, and reviewed the article. J.H. participated in field research, coordinated the work of the project team, and reviewed the article. 
Funding: This study was financed by the Ministry of Science and Higher Education of the Republic of Poland under the project 'Cultural heritage of small homelands' No PPI/APM/2018/1/00010/U/001 financed by the Polish National Agency for Academic Exchange as part of the International Academic Partnerships.

Conflicts of Interest: The authors declare no conflict of interest. The funders had no role in the design of the study; in the collection, analyses, or interpretation of data; in the writing of the manuscript, or in the decision to publish the results.

\section{References}

1. Antrop, M. Landscape change and the urbanization process in Europe. Landsc. Urban Plan. 2004, 67, 9-26. [CrossRef]

2. Plieninger, T.; Kizos, T.; Bieling, C.; Dû-Blayo, L.; Budniok, M.; Bürgi, M.; Crumley, C.L.; Girod, G.; Howard, P.; Kolen, J.; et al. Exploring ecosystem-change and society through a landscape lens: Recent progress in European landscape research. Ecology Soc. 2015, 20, 5. [CrossRef]

3. Pătru-Stupariu, I.; Pascu, M.; Bürgi, M. Exploring Tangible and Intangible Heritage and its Resilience as a Basis to Understand the Cultural Landscapes of Saxon Communities in Southern Transylvania (Romania). Sustainability 2019, 11, 3102. [CrossRef]

4. Benni, S.; Carfagna, E.; Torreggiani, D.; Maino, E.; Bovo, M.; Tassinari, P. Multidimensional Measurement of the Level of Consistency of Farm Buildings with Rural Heritage: A Methodology Tested on an Italian Case Study. Sustainability 2019, 11, 4242. [CrossRef]

5. Power, A.G. Ecosystem services and agriculture: Tradeoffs and synergies. Phil. Trans. R. Soc. B 2010, 365, 2959-2971. [CrossRef] [PubMed]

6. van Zanten, B.T.; Zasada, I.; Koetse, M.J.; Ungaro, F.; Häfner, K.; Verburg, P.H. A comparative approach to assess the contribution of landscape features to aesthetic and recreational values in agricultural landscapes. Ecosyst. Serv. 2016, 17, 87-98. [CrossRef]

7. Bielenda, A. StrachyPolne—Dzieje, Rytuat, Symbolika; The Museum of Scarecrows in Lubenia: Lubenia, Poland, 2013.

8. Sax, B. Crow; Reaktion Books: London, UK, 2003.

9. Lorimer, H. Scaring crows. Geogr. Rev. 2013, 103, 177-189. [CrossRef]

10. Haining, P. The Scarecrow: Fact and Fable; Robert Hale: London, UK, 1998.

11. Warren, J. Scarecrowland. Available online: http://www.scarecrowland.co.uk (accessed on 26 September 2019).

12. Cummings, J.L.; Knittle, C.E.; Guarino, J.L. Evaluating a Pop-up Scarecrow Coupled with a Propane Exploder for Reducing Blackbird Damage to Ripening Sunflower. In Proceedings of the Twelfth Vertebrate Pest Conference, San Diego, CA, USA, 4-6 March 1986; pp. 286-291.

13. World Commission on Culture and Development. Our Creative Diversity; EGOPRIM: Paris, France, 1995.

14. Soini, K.; Birkeland, I. Exploring the scientific discourse on cultural sustainability. Geoforum 2014, 51, $213-223$. [CrossRef]

15. Connelly, S. Mapping sustainable development as a contested concept. Local Environ. 2007, 12, $259-278$. [CrossRef]

16. Bennett, D.; Reid, A.; Petocz, P. Creative workers' views on cultural heritage and sustainability. J. Aesthet. Cult. 2014, 6, 24476. [CrossRef]

17. Agnoletti, M.; Conti, L.; Frezza, L.; Santoro, A. Territorial analysis of the agricultural terraced landscapes of Tuscany (Italy): Preliminary results. Sustainability 2015, 7, 4564-4581. [CrossRef]

18. Vecco, M. A definition of cultural heritage: From the tangible to the intangible. J. Cult. Herit. 2010, 11, 321-324. [CrossRef]

19. Harrison, R. Forgetting to remember, remembering to forget: Late modern heritage practices, sustainability and the 'crisis' of accumulation of the past. Int. J. Herit. Stud. 2013, 19, 579-595. [CrossRef]

20. Backman, M.; Nilsson, P. The role of cultural heritage in attracting skilled individuals. J. Cult. Econ. 2018, 42, 111-138. [CrossRef]

21. Malecki, E.J. Digital development in rural areas: Potentials and pitfalls. J. Rural Stud. 2003, 19, $201-214$. [CrossRef]

22. Garau, C. Perspectives on cultural and sustainable rural tourism in a smart region: The case study of Marmilla in Sardinia (Italy). Sustainability 2015, 7, 6412-6434. [CrossRef] 
23. Keitumetse, S. Cultural resources as sustainability enablers: Towards a community-based cultural heritage resources management (COBACHREM) model. Sustainability 2014, 6, 70-85. [CrossRef]

24. Żmija, D. Sustainable Development of Agriculture and Rural Areas in Poland. Econ. Stud. 2014, 166, 149-158.

25. Muilu, T.; Rusanen, J. Rural definitions and short-term dynamics in rural areas of Finland in 1989-1997. Environ. Plan AEcon. Space 2004, 36, 1499-1516. [CrossRef]

26. de Lima, M.R.T. História e Estórias Do Espantalho; ComissãoMineira de Folclore: Belo Horizonte, Brazil, 2002; pp. 53-69.

27. Szot, S. IwkoweKuseryje; Communal Public Library in Iwkowa: Iwkowa, Poland, 2008.

28. Bielenda, A. Strachy na Wróble [Scarecrows]; The Surcarpathian Centre for Equine-Assisted Therapy; Academy Library for the Programme "Offer Equal Opportunities" (RównaćSzanse): Błażowa, Poland, 2016.

29. Rylant, S. Scarecrow; Houghton Mifflin Harcourt: Boston, MA, USA; New York, NY, USA, 2015.

30. Waterson, M. The Scarecrow. Bright Phoebus. Lal \& Mike Waterson. Available online: https://mainlynorfolk. info/watersons/songs/thescarecrow.html (accessed on 26 September 2019).

31. Bronder, A. Strach oswojony, strach zapomniany? An Attempt at Capturing Traces of Ancient Silesian Beliefs in Contemporary Lexis (based on the example of the name of a quasi-human character of bebok). Ling. Silva 2015, 4, 113-129.

32. Beringer, J.; VerCauteren, K.C.; Millspaugh, J.J. Evaluation of an animal-activated scarecrow and a monofilament fence for reducing deer use of soybean fields. Wildl. Soc. Bull. 2003, 31, 492-498.

33. Gilete, R.M. The Scarecrow, Narnia, and Jesus of Nazareth. Rev. Eur. Stud. 2013, 5, 60-66. [CrossRef]

34. Wigington, P. Scarecrow Folklore and Magic. Learn Religions. Available online: https://www.learnreligions. com/scarecrows-guardians-of-the-harvest-2562307 (accessed on 26 September 2019).

35. Tęcza, K. Zjawy i Strachy Polskie. Typescript. Jelenia Góra. Available online: https://docer.pl/doc/1c5n10 (accessed on 23 October 2019).

36. Wilson, D. Seven High-Tech Scarecrows. Available online: https://modernfarmer.com/2019/08/seven-hightech-scarecrows/ (accessed on 26 September 2019).

37. Burns, K. Brainless, Heartless Scarecrows. Yanko Design. 2009. Available online: https://www.yankodesign. com/2009/04/28/brainless-heartless-scarecrows/ (accessed on 23 October 2019).

38. Homan, H.J.; Slowik, A.A.; Blackwell, B.F.; Linz, G.M. Field Testing Class IIIb Handheld Lasers to Disperse Roosting Blackbirds; National Sunflower Association Sunflower Research Forum: Fargo, ND, USA, 2010.

39. Brown, R. Laser Scarecrows: Gimmick or Solution? University of Rhode Island Vegetable Production Research Reports. Available online: https:/digitalcommons.uri.edu/riaes_bulletin/25/ (accessed on 23 October 2019).

40. VerCauteren, K.C.; Gilsdorf, J.M.; Hygnstrom, S.E.; Fioranelli, P.B.; Wilson, J.A.; Barras, S. Green and blue lasers are ineffective for dispersing deer at night. Wildl. Soc. Bull. 2006, 34, 371-374. [CrossRef]

41. Belant, J.L.; Martin, J.A. Bird Harassment, Repellent, and Deterrent Techniques for Use on and Near Airports; Transportation Research Board of the National Academies of Sciences: Washington, DC, USA, 2011.

42. Baxter, A.T.; Allan, J.R. Use of lethal control to reduce habituation to blank rounds by scavenging birds. J. Wildl. Manag. 2008, 72, 1653-1657. [CrossRef]

43. Pornpanomchai, C.; Homnan, M.; Pramuksan, N.; Rakyindee, W. Smart Scarecrow. In Proceedings of the Third International Conference on Measuring Technology and Mechatronics Automation, Shanghai, China, 6-7 January 2011; pp. 294-297.

44. Swaddle, J.P.; Moseley, D.L.; Hinders, M.K.P.; Smith, E. A sonic net excludes birds from an airfield: Implications for reducing bird strike and crop losses. Ecol. Appl. 2016, 26, 339-345. [CrossRef] [PubMed]

45. RoBird. RoBird@: The Most Effective Bird Control Solution. Available online: https://www.robird.com (accessed on 23 October 2019).

46. Klimaniec, Ł. Święto Stracha Polnego 2018 w Rudzicy. DziennikZachodni. Available online: https://dziennikzachodni.pl/swieto-stracha-polnego-2018-w-rudzicy-jedyne-takie-w-polsce-zdjecia/ ar/13208899 (accessed on 23 October 2019).

47. Król, K. Forgotten agritourism: Abandoned websites in the promotion of rural tourism in Poland. J. Hosp. Tour. Technol. 2019, 10, 461-472. [CrossRef]

48. Cheverst, K.; Coulton, P.; Bamford, W.; Taylor, N. Supporting (Mobile) User Experience at a Rural Village 'Scarecrow Festival': A Formative Study of a Geolocated Photo Mashup Utilising a Situated Display. Available online: https://eprints.lancs.ac.uk/id/eprint/41912 (accessed on 23 October 2019). 
49. Ruijgrok, E.C.M. The three economic values of cultural heritage: A case study in the Netherlands. J. Cult. Herit. 2006, 7, 206-213. [CrossRef]

50. Bowitz, E.; Ibenholt, K. Economic impacts of cultural heritage-Research and perspectives. J. Cult. Herit. 2009, 10, 1-8. [CrossRef]

51. Lazrak, F.; Nijkamp, P.; Rietveld, P.; Rouwendal, J. The market value of cultural heritage in urban areas: An application of spatial hedonic pricing. J. Geogr. Syst. 2014, 16, 89-114. [CrossRef]

52. Garau, C.; Desogus, G.; Coni, M. Fostering and Planning a Smart Governance Strategy for Evaluating the Urban Polarities of the Sardinian Island (Italy). Sustainability 2019, 11, 4962. [CrossRef]

53. Beel, D.E.; Wallace, C.D.; Webster, G.; Nguyen, H.; Tait, E.; Macleod, M.; Mellish, C. Cultural resilience: The production of rural community heritage, digital archives and the role of volunteers. J. Rural Stud. 2017, 54, 459-468. [CrossRef]

54. Ghaderi, Z.; Henderson, J.C. Sustainable rural tourism in Iran: A perspective from Hawraman Village. Tour. Manag. Perspect. 2012, 2-3, 47-54. [CrossRef]

55. Loulanski, T.; Loulanski, V. The sustainable integration of cultural heritage and tourism: A meta-study. J. Sustain. Tour. 2011, 19, 837-862. [CrossRef]

56. Berry, B.J.I.; Baskin, C.W.; Christaller, W. Central Places in Southern Germany. Econ. Geogr. 1967, 43, $275-276$. [CrossRef]

57. Stachańczyk, A.; Truchan, K.; Tutaj, J. Agriculture in Małopolskie Voivodeship; Statistical Office in Kraków: Kraków, Poland, 2017.

58. Sroka, W.; Wojewodzic, T. The Condition and Prospects of the Development of Architecture in Matopolskie Voivodeship, with Particular Emphasis of Support with EU Funds; The Małopolskie Voivodeship Marshal's Office: Kraków, Poland, 2015.

(C) 2019 by the authors. Licensee MDPI, Basel, Switzerland. This article is an open access article distributed under the terms and conditions of the Creative Commons Attribution (CC BY) license (http://creativecommons.org/licenses/by/4.0/). 